\title{
Analysis of Taxation of Income Related To Permanent Establishment According To the OECD Model
}

\author{
MSc. Matjaž Kovač \\ Doctoral candidate, Faculty of Law, University of Maribor, Slovenia
}

\begin{abstract}
Forein Enterprises in case of preforming bussines activity and about taxation of income should consider two or more legal systems or else the legal system of the country in which the enterprise have permantent business activity and the legal system of the country in which resident is enterprise or permanent establishment. For most of the form of income, expecialy income from bussines activity and income from investment activity, the problem of double taxation relief is soluted through Model convention OECD for the avoidance of double taxation with respect to taxes on income and capital (Model OECD). The concept of permanent establishment in its substance binds to the notion of double taxation and the elimination thereof. National legislation of the OECD countries differently regulates the taxation of gains tied to the permanent establishment. The development of world trade, transparent treatment of the OECD Model concerning the abolition of double taxation and ecommerce have resulted to determine the general and specific rules concerning which profits belong to the permanent establishment and how and where it could become taxable.
\end{abstract}

Keywords: taxation, business income, resident, non resident, permanent establishment

\section{INTRODUCTION}

When considering the taxation of multinational companies, the criterion of a permanent establishment should be taken into account. PE is a place of business in which the business of a particular part of a multinational company is wholly or partly carried on. This part of a multinational company is separate from its parent company and it usually represents a nonresident legal entity that is non-resident with respect to the parent company [6]. The generally recognized principle of taxing the business profits of multinational companies is that taxation of the profits of a resident company in a non-resident country is not permitted, unless the resident company operates in a non-resident country through the PE established there [5]. 


\section{3rd International Conference on Research in \\ Business, Management and Economics}

\section{ICRBME}

27-29 November 2020

Dublin, Republic of Ireland

Double taxation treaties provide that profits are taxed in the country in which the resident company is situated, unless it has an PE in the other Contracting State. If the company has an $\mathrm{PE}$ in the other Contracting State, the profits in rePEct of the PE shall be taxable in the country of operation of that PE [4]. Such legal formulation is intended to ensure that the country in which the capital is invested carries out its tax legislation intact. The general criteria for determining the level of profit of an PE are determined in such a way (Article 7 of the OECD Model) that the PE adds to the profit that the PE would gain from operating as a fully independent company. For the purposes of determining profit, taxable expenses include all expenses relating to the business of the business unit, the management expenses and general administrative expenses incurred in the country of business of the PE and in the country of the resident company, if the latter operates in another country through the PE. Another way of determining the profit of an $\mathrm{PE}$, however, relates to cases where the company operates, if it uses the keys to distribute the profit of the whole company among its components. In this case, these keys are used to determine the PE's profit [3].

PE INCOME TAXATION (OECD MODEL ANALYSIS (Article 7)

\subsection{Profit of the entire company}

The first paragraph of Article 7 of the OECD Model reads as follows:

"The profits of an enterprise of a Contracting State shall be taxable only in that State unless the enterprise carries on business in the other Contracting State through an PE therein. If the business operates as mentioned above, the profits of the business may be taxed in another country, but to the extent that s can be attributed to this PE. "

In particular, this is where the question arises of how to differentiate a company profit from the profit taxed by the PE and related to the operation of the PE, since it is precisely where it is generated. The definition of company-wide profit refers to the restriction of taxation rights in an PE country. In theory, two directions have emerged in the development of defining the profit of a company, which is related to the operation of the PE, namely:

determination of taxable profits of the PE through relevant business activities; and

$\square$ the determination of the taxable profit of the PE through the functional division of the company.

Relevant business activities in a non-resident country resulting from the emergence of an PE and also indirectly taxable profit relate to business activities in which the PE plays a role. In doing so, the rule should be taken that the profits from the relevant business activities of the PE must not exceed the profits made by the whole company in the area concerned. The profit of the entire company is that obtained by the company through business activities through third parties, as well as through business activities through controlled transactions with related parties. Recent activities are subject to the control of transfer prices, which must be corrected on an unrelated market price principle. In addition, the profit of the entire company is related 


\section{3rd International Conference on Research in}

\section{ICR $\mathrm{BME}$}

Business, Management and Economics

27-29 November 2020

Dublin, Republic of Ireland

to both revenue and expenses from the entire business activity. If the relevant business activities relate to operations with other parts of the company and these activities result in a loss, the loss actually incurred on other activities affects the profit of the PE. In this case, the loss affects the overall profit of the company related to the relevant business activities. Only loss that is not related to the relevant business activities of the PE does not reduce the taxable profit of the PE [9].

Among the countries that have adopted this method, there are many differences in how to adopt relevant business activities in practice. The breadth of precision in the definition of relevant business activities has a major impact on the fact that the above-mentioned operating system will have any practical implications. The performance of other parts of the company has a decisive influence on the PE's profitability relationship with relevant business activities. If the relevant business activities relate to the entire business activity of a product, it will not be possible to say isolate the profits of the PE, even though the activity of the PE is only in the distribution function of the company. Relevant business activities should be narrower in definition of the PE functions themselves and may not include the involvement of other company activities. Identifying relevant business activities becomes more difficult if both PEs and other parts of the company participate in similar business activities. The right to tax a nonresident company may also be restricted if relevant business activities are taken into account in the sense that profits may not be linked to the PE, unless the business activities relate only to the jurisdiction of the non-resident country.

It is also important to determine the period of consideration of relevant business activities. In the event that business activities result in a one-year loss, we will not be able to cover them through the profit associated with the PE activities for that period if we have determined the relevant business activities for a longer period of time. Some countries consider relevant business activities in their gross income, while some link these activities separately for income and separately for costs. Again, some countries link relevant business activities to the net profit of different parts of the company [2].

The second approach to resolving the taxable profit of the PE is aimed at the functional division of business activities or the company into several units. This approach does not limit the profits that are tied to the PE in relation to the relationship with the profits of the whole company. The profits attached to the operation of the PE are only those obtained by the PE on the basis of comparable market prices, provided that the companies are separate from each other and carry out similar activities in similar circumstances. The vast majority of countries consider the link between taxed profits, where assets derived from PE assets within a nonresident country are transferred to another country. Functional division of business activities takes into account the profits associated with the PE, although they have not yet been realized throughout the company. On the other hand, the relevant business activities are not linked to the profits of the $\mathrm{PE}$, unless they have been realized with the company through transactions with other business entities. In the event that the domestic and foreign companies adopt different methods of accounting for PE profits, this can lead to double taxation. In addition to the aforementioned spills, the PE's profit system should also be considered. In the functional division of business activities, we have an PE business start point, while in the relevant business activities, we have a basic point in the business activities of the entire company. When the profits of the whole 


\section{3rd International Conference on Research in \\ Business, Management and Economics}

\section{ICR 8 ME}

27-29 November 2020

Dublin, Republic of Ireland

company are equalized by both methods, there is no double taxation. Consequently, this has an impact on the observance of the comparable market price method, since it is taken into account in both of these approaches [10].

Simplifying the comparison between the two principles of determining the profit of the whole company, we find that business entities with different approaches to solving the problem in question can differently solve the problem of double taxation. Double taxation will be strongest when one entity adheres to the principle of functional profit sharing and the other to profit based on relevant business activities. Some countries are of the view that functional profit sharing is the best approach because it is simpler, administratively easier and more consistent in complying with comparable market prices. Nor does it impose any restriction on profits on profits associated with the operation of the PE, which is to have a retroactive effect on the determination of the profits of the PE with rePEct to comparable market prices. From an administrative point of view, the principle of functional profit sharing is more successful, in particular, because it does not require a non-resident country to determine precisely the global income from the relevant business activities of a company. In addition, it also eliminates the redetermination of taxation when the period is different depending on the determination of the relevant business activities. As regards the more consistent adherence to comparable market prices, the principle of functional profit sharing is more successful because it represents a PEcial type of approach when the PE is a legally separate entity.

\subsection{Profits related to the operation of the PE}

The second paragraph of Article 7 of the OECD Model reads as follows:

"If an enterprise of a Contracting State conducts business in the other Contracting State through an PE therein, in each of the Contracting States, such profits shall be attributed to that other PE, which could be expected to have been generated if it had been an independent and separate undertaking engaged in equal treatment. or similar activities under the same or similar conditions and would operate completely independently of the company of which the PE is. "

The OECD model considers the PE as a separate entity carrying out similar activities on similar terms and considers profits by applying the rule of comparable market prices. The aim of the OECD Model approach is not to achieve equal profit between PEs and affiliates or parent companies, but to set rules between different parts of a single entity on the basis of the transfer pricing principle arising from related party transactions. The OECD model will achieve a level playing field between different types of PEs, but will not achieve a level playing field between branches and PEs, reflecting the differences between the two entities. The use of a legal form (branch or PE) may have some economic effects that affect the determination of taxable profit. Businesses through the PE could be described as much more profitable, because through the PE we can influence efficient capital balance, risk distributions and increased economic insurance.

The actual and functional analysis of the OECD Model is based on the depiction of the PE as a formation that differs from the rest of the company, ePEcially in terms of different and separate functions and different and separate operating conditions. Functional analysis must also take 


\section{3rd International Conference on Research in \\ Business, Management and Economics}

\section{ICRßME}

27-29 November 2020

Dublin, Republic of Ireland

into account the assets used in the production process as well as the risk of operating business functions. It is ePEcially important to take into account the risk functions of the company that relate to the distribution of assets and risk. The basis of a company's risk function varies with different business sectors. Separation must be made on the basis of a comparison of operations, while the basic functions of risk and their relative importance depend on PEcific facts and circumstances. It is also important to audit the other functions of the company in the light of comparable market pricing rules. Actual and functional analysis refers to the determination of the profit of an PE with rePEct to its function, the assets it uses and the risk involved [11] .

The actual and functional analysis investigates all the facts and circumstances in which the assets of the company were used for the functions and operation of the PE and the conditions under which the assets were used. In doing so, it also takes into account the factors that determine which parts of the entire enterprise have been trained and designated as the carrier of economic activity in the property. The analysis in question gives us the answer to the question whether the property was created through the activities of the company itself or together with the activities of other companies. The asset function and its classification results in the coformation of the profit function and the capital ion function of the PE debt. The function of the related and unrelated assets of the PE is based on economic ownership, which is the result of the actual and functional analysis of the two parts of the whole enterprise (the parent company and the PE) involved in the transaction. The risk function of the business with rePEct to the distribution of the assets of the PE must also be taken into account. The PE profit function relating to the rule of comparable market prices is formed by[7] :

$\square$ the presentation of the functions, assets and risks between the PE and the rest of the company, which is designed in the light of factual and functional analysis, while not forgetting the operations that may be characteristically characterized;

$\square$ presentation of capital relating to the assets and risk associated with the PE;

$\checkmark$ price representations based on comparable, market-based pricing that are easily established and have passed the threshold test;

$\checkmark$ identifying transactions between the company and independent third parties that are in business relationship with the PE;

$\checkmark$ determining comparability between transactions and uncontrolled transactions, which are formed by the use of comparable factors directly or by analogy of them, in the direction of the PEcific real circumstances of the PE; and

$\checkmark$ fixing compensation for comparable market prices in rePEct of the activities that the PE develops. In doing so, it should be borne in mind that the assets and risks of the assets of the PE that have arisen through the adherence to traditional transaction methods or traditional methods of determining profit.

In view of the aforementioned provision of the second paragraph of Article 7 of the OECD Model, two stages of determining the profit associated with the operation of the PE have been established, namely:

defining the activities and conditions for the demarcation between the PE and other parts of the company; and 
$\square$ determination of profits to distinguish between PEs and other parts of the company on the basis of benchmarking.

For a comparative analysis of the activities and the conditions of demarcation between an PE and a company, it is necessary to define the relevant economic characteristics that influence the determination of the activities and conditions. It is necessary to compare the characteristics of transactions or business activities that have an impact on the functioning of conditions in a system of comparable market prices. The demarcation conditions can be separated into internal and external. Internal conditions of demarcation refer to actual and functional analyzes of the characteristics of a company, while external conditions are determined by external environmental elements. Summarizing the content, the first step is to take into account the functional and actual analysis of the PE's functioning in terms of defining functions according to different and separate companies and the economic elements for presenting these functions [12].

When analyzing the functions of an PE, we must pay particular attention to the consideration of usable assets and the foreseeable business dangers. In doing so, we must take into account the actual analysis of all relevant economic characteristics and conditions relating to the operation of the PE. Some elements, along with functional analysis, are important to consider when comparing operating conditions. These elements must also be taken into account when looking at the factors of functional analysis for determining the conditions of separation between different parts of a company. Elements must contain the same positions as those of the PE. It should be emphasized that the profit of the PE is related to the operating conditions of the company, which are related to those operating conditions of the PE, which are PEcifically related to the PE activity itself. The PE's distribution function is linked to the relevant income determination step as it reflects relevant economic attributes through the identification of a business strategy. In doing so, the right business strategy of the PE must be taken into account and this can only have a significant impact on the determination of the business between the PE and other parts of the company, taking into account transactions between unrelated persons. Functional analysis should provide an answer to what are the important economic activities carried out by the PE and how they are reflected in the functioning of the whole company. Some of these activities are linked to a permanent place of business, which is often linked to the legal competence of the PE. However, it is important that the functional analysis contains not only activities relating to the jurisdiction of the PE but also activities in favor of the PE as well as all activities in favor of the PE taken into account by other parts of the company. Such activities will be taken into account when the associated profit of the PE, regardless of the precise purpose of the operation, will depend on the analysis of the facts and circumstances. Above all, functional analysis must work on the precise nature of the functions that are relevant to the operation [13] .

Functional analysis must also take into account the assets used, as well as the operations through branches. The determination of the assets used and the protection of the PE's activities is difficult to determine, ePEcially when these elements fall within the business of the entire company. An economic criterion is decisive for determining the PE's income taxation system, since it has a major effect on the economic cohesion between different parts of a legal entity. The legal position of the property belongs to the whole company. In doing so, it is necessary to 


\section{3rd International Conference on Research in \\ Business, Management and Economics}

\section{ICR $B$ ME}

27-29 November 2020

Dublin, Republic of Ireland

answer the question of whether the PE uses the assets of the whole company in relation to its business, and if so, on what basis. Certain facts and circumstances must be confirmed in order to determine the extent to which assets can be used in relation to the activities of the PE. This property must also be linked to the profits derived from the operation of the PE. In the case of PEs, the tax authority will first start checking individual company accounts. It may happen that certain assets will not be booked with the PE. In this case, this property may be taken into account in relation to the profit earned on the property. The taxpayer must pay particular attention to the methodology used to determine the PEcific profits of the PE [1] .

Insurance is an activity that applies to the entire company, but in economic terms, the elements of insurance can also be considered for the PE as a whole. In this case, the insurance should cover exclusively the PE's activity. The relationship between the insurance of the PE's activities has a direct consequence in determining the formation of capital and capital for the operation of the PE. Mainly due to the increase in capital in terms of collateral, on the other hand, the capital that is intended to cover credit facilities in the PE is increasing. In the absence of contractual provisions between the company and the $\mathrm{PE}$, the rates of insurance and liability within the company shall be determined and all shall be settled on the basis of comparable, unrelated transactions. The resulting deduction must be related to:

$\square$ identifying and verifying internal links between the company as a whole;

$\checkmark$ making comparisons of how other unrelated companies would behave;

$\checkmark$ identifying and verifying inside information;

u examining documentation that illustrates how insurance was taken into account by a company.

\subsection{Costs related to the operation of the PE}

The third paragraph of Article 7 of the OECD Model reads as follows:

"The deduction of costs incurred for the purposes of the PE, including the management and general administrative costs incurred either in the country in which the PE is located or elsewhere, shall be allowed in determining the profits of the PE."

Several theories have emerged regarding the costs associated with the operation of the PE. Two theories are particularly important. In the first place, the OECD Cost Provisions are primarily set up to cover the costs of the PE, which should not be made on incorrect assumptions, mainly because the costs are out of reach of the PE or are not directly related to the operation of the PE. The second theory relates to the system of comparative market prices and has two orientations, namely[8] :

the costs incurred by the PE must be deducted, although they are higher than the comparative market price system;

$\square$ other parts of a company cannot cover more costs than those related to the costs incurred in the operation of the PE, unless the costs are related to the operations of third parties. 


\section{3rd International Conference on Research in \\ Business, Management and Economics}

\section{ICRBME}

27-29 November 2020

Dublin, Republic of Ireland

The basic purpose of the provision is to ensure that the relevant costs are deducted in relation to the PE's income, without contradicting the system of comparable market prices. In some companies with two or more business units, cost forms have to be allocated to achieve separate accounting. This results in the bookkeeping of foreign business units on the same basis as domestic companies. This raises the question of whether certain deductions for calculating the PE's profit for certain types of costs should be considered as actual costs or as costs on the basis of comparable market prices. The primary purpose of this provision in the OECD model seems to be to ensure that the PE's operating costs can be deducted based on the PE's profit, regardless of where that profit is generated.

\subsection{Division of profits of the whole company into different parts}

The fourth paragraph of Article 7 of the OECD Model reads as follows:

"If it was customary in a Contracting State to determine the profits attributable to the PE on the basis of the distribution of the total profits of the enterprise into different portions, it cannot prevent that Contracting State from determining the profits to be taxed by such distribution as is customary. However, the method of distribution must be in line with the principles of world taxation."

The above rule can only be rePEcted if the total profit to be distributed can be distinguished from the individual transactions by the basic characteristics of the taxation of the PE's business. This conception of taxing the business of an PE is very unknown, unless PE is the holder of all activities related to the whole company, so that the rest of the company operates in only one business activity.

In some countries, it is common for profits to be attributed to the PE to be determined not on the basis of separate accounting or profit estimation, taking into account the principle of comparability of market prices, but by dividing the profits of the enterprise as a whole into parts. Such a method of distribution leads to different results than would be obtained if the profit of the PE were determined by considering or determining the profit on the basis of separate accounting for the PE. A characteristic of the method of distributing all the profits of an enterprise into its parts is that the proportionate share of the profits of the whole enterprise is attributed to the constituent of the enterprise, assuming that all parts of the enterprise contribute to the profit of the whole, taking into account uniform criteria. The State may use the method of distributing the profits of an enterprise into its parts when determining the profits of an PE. It may use such a method even though the result obtained by such a method of distribution is in some cases different from that which would be achieved under other rules. Regardless of whether the profit of the PE is determined in accordance with the general principles or by the method of distributing all profits of the enterprise into its parts, the result obtained by applying the individual method must be in accordance with the principles of taxation of the profit of the PE. 


\section{3rd International Conference on Research in \\ Business, Management and Economics}

\section{ICRBME}

27-29 November 2020

Dublin, Republic of Ireland

\subsection{PEcific ways of dealing with PE profits}

Article 7 (5) of the OECD Model reads as follows:

"PE is not credited with profits because it only purchases goods and merchandise for the company."

Activities which, although carried out through a permanent place of business, do not constitute an PE also include undertakings whose sole activity is to purchase goods for another undertaking. When an PE carries out activities other than ancillary or preparatory activities in addition to the purchase of goods or merchandise for the enterprise, the issue of attribution of the PE's profits does not arise when the sole activity of the PE is the purchase of goods or merchandise for the enterprise, since it does not constitute an PE.

Article 7 (6) of the OECD Model reads as follows:

"The profit attributable to the PE shall be determined by the same method year after year, unless there is good and sufficient reason to the contrary."

PE taxation is based on the same principles over time, which implies consistent taxation and legal certainty for the taxpayer. The method used in taxing an PE should not be changed solely because the use of another method in a given tax year would lead to more favorable results for the PE. One of the purposes of the OECD Model is to provide security for an enterprise that has an PE in another country so that it can rely on applicable regulations in that country and provide for tax treatment of its PE.

Article 7 (7) of the OECD Model reads as follows:

"If profit includes parts of income that are dealt with separately, only such income is treated separately."

Some articles in the OECD Model Model address the taxation of certain types of income, in particular the provisions that take precedence over the application of the PE income tax provisions.

\section{CONCLUSION}

As regards the taxation of non-residents, it is of the utmost importance to consider the criteria for eliminating double taxation, since the taxation system of world income, due to the specific characteristics of world income, almost always causes the appearance of double taxation. The theory and practice have formulated two basic criteria for eliminating double taxation. The first criterion is linked to the source of income and has its confirmation in the fact that the tax is directly linked to the income, which is organically linked to the area where it was obtained. Thus, the countries of origin restrict their tax legislation only to the taxation of income originating in that national territory. The second criterion concerns the notion of residence. Confirmation of resident taxation can be determined by linking income tax to income use. Even 


\section{3rd International Conference on Research in \\ Business, Management and Economics}

\section{ICR 8 ME}

27-29 November 2020

Dublin, Republic of Ireland

if the income is obtained in an area outside a state territory, it is likely that he or she will return to the territory where the entity that obtained such income resides or has permanent business functions in that territory. Income earned abroad, where it has its primary source and transferred to the country of residence, contains, in addition to its net economic value, the amount of tax paid by the entity to the tax authorities of the foreign country according to their sovereign tax law. . In this case, the country of residence prevents or completely eliminates double taxation of income through specific methods that take into account, on the one hand, income for taxation in the resident country and, on the other hand, tax for taxation in the resident country. The tax exemption method in a resident country does not take into account income earned abroad, since tax has already been paid on that income; for the tax deduction method, however, the tax deduction paid abroad with respect to the total tax liability on the entity's global income is taken into account.

As regards the taxation of non-residents, the rule of the method of deduction of tax paid abroad was adopted, which is in accordance with the accepted method of unlimited tax liability. The exemption method can only be used where we have tax at source, which means that this method is only applicable when calculating income tax on individual income sources that are subject to income tax.

In some countries, it is common for profits to be attributed to the PE to be determined not on the basis of separate accounting or profit estimation, taking into account the principle of comparability of market prices, but by dividing the profits of the enterprise as a whole into parts. Such a method of distribution leads to different results than would be obtained if the profit of the PE were determined by considering or determining the profit on the basis of separate accounting for the PE. A characteristic of the method of distributing all the profits of an enterprise into its parts is that the proportionate share of the profits of the whole enterprise is attributed to the constituent of the enterprise, assuming that all parts of the enterprise contribute to the profit of the whole, taking into account uniform criteria. The State may use the method of distributing the profits of an enterprise into its parts when determining the profits of an PE. It may use such a method even though the result obtained by such a method of distribution is in some cases different from that which would be achieved under other rules. Regardless of whether the profit of the SPE is determined in accordance with the general principles or by the method of distributing all profits of the enterprise into its parts, the result obtained by applying the individual method must be in accordance with the principles of taxation of the profit of the PE.

\section{REFERENCES}

[1] Augustyniak P., The Relevance of the Permanet Establishment Concept fort he Allocation of Income from Employment, v Lang M. et.al., Permanent Establishments in International and EU Tax Law, 1. Auflage, linde Verlag Vienna 2011, str. 261265.

[2] Ceballos A.S., The Permanent Establishment Definition v Lang M. et.al., Permanent Establishments in International and EU Tax Law, 1. Auflage, Linde Verlag Vienna 2011, str. 59-70. 


\section{3rd International Conference on Research in \\ Business, Management and Economics}

\section{ICRBME}

27-29 November 2020

Dublin, Republic Of Ireland

[3] Jann M.: How Does EC Law Affect Benefits Available to Non-Resident Taxpayers under Tax Treaties, Tax Treaties and EC Law, Series on International taxation no. 16, Kluwer Law International, London, 1997, str. 15-27.

[4] Lang M. et.al., Tax Treaty Law and EC Law, 1. Auflage, Linde Verlag Vienna 2007, str. 169-178.

[5] Lang M.. et.al., The OECD Model Convention and its Update 2014, 1. Auflage, Linde Verlag Vienna 2015, str. 202-226

[6] Lang M.: The Binding Effect of the EC Fundamental Freedoms on Tax Treaties, Tax Treaties and EC Law, Series on International taxation no. 16, Kluwer Law International, London, 1997, str. 17-20.

[7] LewickiIssue T.: International - A Construction Consortium as a Permanent Establishment from an International Tax Law PerPEctive: Inconsistencies and Deficiencies in Article 5(3) of the OECD Model and Commentary, Bulletin for International Taxation, 2012 (Volume 66), str. 45-65.

[8] Pechota F., The Interrelation between teh Attribution of Profits unde Tax Treaty Law and the Realization of Profits udner Domestic Law, v Lang M. et.al., Permanent Establishments in International and EU Tax Law, 1. Auflage, Linde Verlag Vienna 2011, str. $171-183$.

[9] Radhakishan R.: The Taxation of Permanent Establishments An International PerPEctive Spiramus Press, London, 2006, str. 2-14.

[10] Reimer E., Urban N., Schmid S.: Permnanent Establishments, A Domestic Taxation, Bilateral Tax TreatY ad OECD PerPEctive, Wolters Kluwer Law and Business, Kluwer Law Intenational, The Netherlands, 2011, str. 10-26.

[11] Sagmeister C., The Construction Permanent Establishment v Lang M. et.al., Permanent Establishments in International and EU Tax Law, 1. Auflage, Linde Verlag Vienna 2011, str. 71-85.

[12] Tuffer I., The Attribution of Capital to Permanent Establishment, v Lang M. et.al., Permanent Establishments in International and EU Tax Law, 1. Auflage, Linde Verlag Vienna 2011, str. 203-205.

[13] Waltrich A.: Cross-Border Taxation of Permanent Establishments: An International Comparison, Series of International Taxation, Kluwer Law International, 2016, str 87-96 